\title{
The influence of entrepreneurial orientation on firm growth among Iranian agricultural SMEs: the mediation role of entrepreneurial leadership and market orientation
}

\author{
Asef Karimi $^{1}$ • Mahmood Ahmadpour Daryani ${ }^{2} \cdot$ Soma Rahmani ${ }^{3}$ \\ Received: 7 December 2019 / Accepted: 28 February 2021 / Published online: 17 August 2021 \\ (C) The Author(s) 2021
}

\begin{abstract}
Entrepreneurship orientation is a fundamental topic both in entrepreneurship and in management that has a critical role in the development of the firm. The purpose of this paper is to study the relationship between entrepreneurial orientation (EO) and firm growth, specifically, how entrepreneurial leadership and market orientation mediate the relationship between EO and firm growth. The population of this study is agricultural small- and medium-sized enterprises (ASMEs) across Tehran Province. The survey instrument is questionnaires that were sent to 240 owners and/or top managers of ASMEs as a sample. Validity of the questionnaires has been verified in two ways of face and construct, and its reliability has been verified using Cronbach's alpha. The collected data has been analyzed by using the structural equation modeling. The results reveal that EO significantly influences firm growth in ASMEs. Notably, entrepreneurial leadership (EL) and market orientation (MO) perform a mediating role in the relationships between EO and firm's growth in ASMEs.
\end{abstract}

Keywords Entrepreneurial orientation $\cdot$ Entrepreneurial leadership $\cdot$ Market orientation $\cdot$ Firm growth

\section{Introduction}

The agricultural sector in Iran accounts for an increasing share of the economy; therefore, the growth of the agricultural sector can play an essential role in economic growth (Khorami \& Pierof, 2013). This sector is grappling with new challenges due to rapid environmental changes. Dealing with these difficulties, some measures would be essential. In this regard, both entrepreneurial orientation (Gellynck et al., 2015), and the role

Asef Karimi

Asef.karimi@ut.ac.ir

Mahmood Ahmadpour Daryani

Ahmadpor@ut.ac.ir

Soma Rahmani

Srahmani@umz.ac.ir

1 Faculty of Management and Accounting, College of Farabi, University of Tehran, Tehran, Iran

2 Faculty of Entrepreneurship, University of Tehran, Tehran, Iran

3 Faculty of Economics and Administrative Sciences, University of Mazandaran, Babolsar, Iran of small- and medium-sized agricultural enterprises are noticeable since $98.4 \%$ of the businesses are small enterprises in Iran (Popovic et al., 2009), and about 54.4\% of SMEs are agricultural enterprises (Popovic et al., 2009).

SMEs can have a significant impact on the development of the national economy. They mobilize national resources, create job opportunities, raise wealth, and reduce poverty in society. They can also play a critical role in privatization through the attraction of human resources. They lead the society to democracy and civilization in which entrepreneurs can cooperate in the economic, social, and political systems of a nation. Furthermore, their innovativeness and agility to deal with environmental changes and uncertainties are remarkable.

Although SMEs in various sectors play an essential role, there are barriers that increase their failure rate in the first five years to more than $50 \%$. These problems include lack of ability to maintain staffing, lack of appropriate management experience and advisory services, limited financial resources and lack of financial support by institutions, the problem of raw material supply and difficulty in product sales, poor economic conditions and policies, and lack of success in marketing because of insufficient market research. ASMEs in Tehran 
Province also have constraints that high start-up costs and lack of knowledge among managers and authorities are the most challenges (Pourjavid et al., 2013).

Such barriers have led Iran's position in terms of business success and ease of doing business according to the population and the gross national income (GNI) per capita in the ranking 152 among 189 countries (Arasti et al., 2014). Hence, it is significant to research and explore the causes, tackle the problems, as well as contribute to the growth of the organization. Several studies in recent years have been done on the factors influencing the growth of SMEs.

The role of market orientation based on the knowledge of the market, competitors, and customers has a considerable effect on the growth of SMEs. To grow, SMEs need employees and owners with sufficient competency in the areas of leadership and management. EO and entrepreneurial leadership in the entrepreneurial approach of SMEs can help in identifying and exploiting opportunities and setting the right prospects for the future (Lockett et al., 2013). Unlike many studies in Iran that have worked on the impact of entrepreneurial activities on SMEs' performance in industries, only a few have focused on the agricultural sector (Hosseini \& Eskandari, 2013). Given the importance of EO, this study examines ASME growth in Iran, and tries to show how market orientation and entrepreneurial leadership mediate the relationship between EO and ASME growth.

\section{Literature review and `development}

\section{Entrepreneurial orientation}

$\mathrm{EO}$ as a new subject has attracted many researchers in the past decade (Lumpkin \& Dess, 1996; Coulthard, 2007; Vidic, 2013). EO includes entrepreneurial activities and strategic orientation in the organization that lead to entrepreneurial decision-making such as proactiveness, innovation, and risktaking (Vidic, 2013).

In various studies, proactiveness, innovativeness, and risktaking are highlighted as the three basic dimensions of EO (Lumpkin \& Dess, 1996; Chen et al., 2012; Cools \& Van den Broeck, 2007). Some other researchers have added two more items, including competitive aggressiveness and autonomy to the previous dimensions of EO (Pearce et al., 2010; Polonsky et al., 2005). In another study, Antoncic and Hisrich (2001) have used new business venturing and self-renewal instead of innovation and leadership. In this study, EO consists of proactiveness, innovativeness, new business venturing, and strategic renewal.

a) Innovativeness. Neely and Hii (1998) introduce innovativeness in three levels: (1) at the product level, for the development of new products and services; (2) at the process level, for the creation of new methods of production and distribution; and (3) at the organizational level, for changes in the management, workforce skills, and activities of the organization.

b) Proactiveness. Proactiveness means looking for new opportunities as a pioneer in the market (Coulthard, 2007).

c) New business venturing. It creates new businesses in the existing organizational structures through a re-definition of existing products and creating new markets (Antoncic \& Hisrich, 2001).

d) Strategic renewal. Strategic renewal has been used in several areas such as strategic management as a strategic change, corporate entrepreneurship as the creation of new business within the existing organization, organizational design, and dynamic performance studies (Rajes, 2013).

\section{SME growth}

The growth of a company is regarded as the company's success and a source of survival and wealth creation. Growth is affected by a wide variety of factors, such as uncertain environments and unpredictable markets (Stenholm et al., 2016). Numerous studies have been conducted on how a company grows, but a comprehensive model to describe the growth of the company is not provided. Penrose (1959) considers the company's growth in two ways: (1) an increase in output, sales rate, and the amount exports, and (2) an increase in the size of the company and its development process which is an increase in employment, assets, output, market share, and profits (Omar et al., 2014). In many studies, increased sales and employment rates have been considered to measure the growth of the company (Stenholm et al., 2016; Ferreira \& Azevedo, 2008; Koryak et al., 2015).

Therefore, in this study, given the abundant indices in various articles, sales growth and employment growth are used as the indices for measuring the growth of ASMEs.

\section{Market orientation}

Following the changes in markets and their globalization, the concept of market orientation drew the attention of many researchers (Maleki et al., 2013; Hussain et al., 2016; Prifti \& Alimehmeti, 2017). MO is a competitive strategy that affects all sectors and levels of an organization and market partners such as customers, distributors, competitors, and environment (Maydeu-Olivares \& Lado, 2003). Market orientation in SMEs is different from large organizations. In many studies, market orientation has involved the three dimensions of customer orientation, competitor orientation, and inter-functional coordination (Liu et al., 2013; Awwad \& Agti, 2011; Ghanavati, 2014). 
a) Customer orientation. Customer orientation is an organizational culture in which the strategies grow by focusing on customers (Hussain et al., 2015).

b) Competitor orientation. The company with this tendency focuses on the strengths and weaknesses, strategies, and the long-term capabilities of potential and actual competitors in the market, and it provides some information for the organization (Liu et al., 2013).

c) Inter-functional coordination. It is a dimension of the market orientation approach that coordinates the members and organizational sectors to meet the customers' needs (Ghanavati, 2014).

\section{Entrepreneurial leadership}

Researchers have used the entrepreneurial leadership approach to investigate how entrepreneurial behaviors in organizations develop (Renko et al., 2015). Entrepreneurial leadership has both the characteristics of leaders and the characteristics of entrepreneurs, and it is a kind of leadership that emerged in the entrepreneurial literature (Huang et al., 2014).

Various aspects of entrepreneurial leadership have been investigated in several studies. Mousavihejazi et al. (2012) have suggested strategic, communicative, personal, and motivational dimensions for entrepreneurial leadership, each with its own components. Renko et al. (2015) introduced the dimensions of vision, opportunity orientation, power of influence, planning power, ability to motivate others, achievement, creativity, flexibility, patience and resilience, risk-taking, tolerance for ambiguity, high self-confidence, proactiveness, and self-control. Therefore, in this study, the most frequent dimensions in the literature review of entrepreneurial leadership, including visionary, charisma, creativity, and risk-taking, are taken into account.

a) Visionary. It, with a future-oriented nature, is a concept in leadership literature that shows an organization's expected value (Ruvio et al., 2010).

b) Charisma. It is one of the leadership qualities that is known as transformational leadership. It is a kind of idealized influence on people that encourages them to perform tasks in the light of the expectations and visions of the organization (Lee, 2008).

c) Creativity. Creativity is one of the capabilities of transformational leadership in providing new ideas and thinking that can play an essential role in supporting innovation and adapting to the changes (Hyypiä \& Parjanen, 2013).

d) Risk-taking. Risk-taking is a willingness to accept uncertainty in the environment and take responsibility for its consequences (Agbim et al., 2013).

\section{Entrepreneurial orientation and growth}

Several studies are about the effect of EO on organizational performance (Kraus et al., 2012; Fairoz et al., 2010; Hosseini \& Eskandari, 2013). The results of research conducted by Setyanti et al., 2013) have shown the positive impact of EO on the performance of SMEs with the mediating role of innovation. Despite numerous studies on the impact of EO on performance, its impact on growth and development dimensions is less studied. According to this view, the company's growth is considered changes in the internal and external environment. Therefore, the growth of a company can be regarded as a type of entrepreneurship (Gürbüz \& Aykol, 2009). Thus, according to a literature review presented, the following hypothesis arises.

Hypothesis 1: EO has a positive impact on ASME growth.

\section{Entrepreneurial orientation and market orientation}

Entrepreneurs, founders, and owners of SMEs play a vital role in the development of a company. SMEs with a high propensity for entrepreneurial activities always do R\&D activities. They have an active market awareness to identify new opportunities in the market and identify the future needs of customers in order to respond quickly to their demands. As a result, it is said that market orientation and market research can provide the required information about customers, competitors, and organization. EO coordinates the resources and activities of an organization in line with its objectives to serve the customer and market better (Sidik, 2012), although researchers have suggested that EO has a positive impact on performance (Fairoz et al., 2010), and market orientation, in turn, affects the performance of organizations (Maleki et al., 2013; Ghanavati, 2014).

Many researchers have concluded that these two orientations cannot lead to performance development and improvement in an organization. EO needs to use capabilities such as market orientation to achieve its goals more efficiently and effectively (Murray et al., 2011; Kajalo \& Lindblom, 2015). Thus, these arguments lead to the second hypothesis.

Hypothesis 2: EO is positively related to market orientation in ASMEs.

\section{Entrepreneurial orientation and entrepreneurial leadership}

A tendency to entrepreneurial activities depends on entrepreneurial development in an organization. El-Annan (2013) argues that although leadership is not an EO by nature, it has any type of leadership behavior such as innovation, visionary, and the actual behavior which is associated with entrepreneurship. In research by Agbim et al. (2013), entrepreneurial development was defined as a desire for innovation by individuals or a 
group of people through networking in order to develop organizational capabilities to meet the environmental goals and to deal with the unpredictable environment. In this definition, four dimensions are raised, namely entrepreneurial intention, entrepreneurial networking, entrepreneurial capability, and entrepreneurial success. The entrepreneurial capability has four dimensions of technological skills, managerial skills, personal skills, and entrepreneurial leadership. Therefore, the following hypothesis is:

Hypothesis 3: EO is positively related to entrepreneurial leadership in ASMEs.

\section{Market orientation and growth}

Market orientation is a vital source of obtaining a competitive advantage in the market through customer surveys and marketing. Therefore, it can have a significant impact on the performance of the organization. Several studies have pointed to the positive impact of market orientation on performance (Micheels \& Gow, 2008; Rahab, 2012). In this regard, we conjecture the following hypothesis:

Hypothesis 4: Market orientation is positively related to ASME growth.

\section{Entrepreneurial leadership and growth}

The growth of SMEs depends on the potential growth available in leadership and organizational development capabilities. Leadership knowledge and entrepreneurial experience play an important role in identifying opportunities. The diversity of knowledge and entrepreneurial leadership experience in identifying opportunities have a positive impact on the growth of an organization (Lockett et al., 2013). Jagdale and Bhola (2014) suggest that entrepreneurial leadership contributes to the effectiveness and improvement of organizational performance. According to the above argument, we hypothesize:

Hypothesis 5: Entrepreneurial leadership is positively related to ASME growth.

\section{The mediating role of market orientation and entrepreneurial leadership}

In several studies about the effect of EO on performance, either the issue has been examined in the direct relationship (Hosseini \& Eskandari, 2013; Kabiri \& Mokshapathy, 2013) or several intermediary variables have been used to evaluate the relationship. Boso et al. (2013) have employed market orientation as a mediator in the relationship between EO and performance in the developing economies. Additionally, they consider EO and market orientation as the decision-making process that plays an essential role in such economies. Moreover, Aljanabi et al. (2015) have applied market orientation as a mediating role to investigate the relationship between EO and technological innovation capabilities. They also have examined the relationships between absorptive capacity and technological innovation capabilities. Hunter (2013) has employed the mediating role of entrepreneurial leadership to examine the competitiveness of SMEs producing food and drink in the southwest of the UK and evaluated the relationship between social capital, entrepreneurial leadership, and entrepreneurial activity. According to the literature review on the mediating role of market orientation and entrepreneurial leadership, the following hypotheses are presented:

Hypothesis 6: Market orientation mediates the relationship between EO and growth among ASMEs.

Hypothesis 7: Entrepreneurial leadership mediates the relationship between EO and growth among ASMEs.

\section{Research framework}

From the preceding discussion, the causal relationships have been illustrated in the research model, as shown in Fig. 1.

\section{Research method}

The methodology of this paper includes data collection, measurement instruments, data analysis, validation of measurements, and reliability of measurement. The research method in this study is quantitative and based on descriptive-survey research that uses surveys to gather data about the influence of EO on firm growth.

The population of this study is agricultural small- and medium-sized enterprises (ASMEs) across Tehran Province in Iran, which have registered to the Small and Medium Industrial Advisory Data Bank website $(\mathrm{N}=1123)$. According to the Bartlett et al. (2001) table, the sample size 240 was selected using a stratified random sampling method. It has to say that samples have been selected from different regions of Tehran, for example 50 ASMEs from Eslamshahr, 15 from Pardis, 125 from Tehran, 10 from Damavand, 18 from Pakdasht, 7 from Varamin, 8 from Rey, and 12 from Shahriar. The survey instrument was applied to the owner/managers of micro, small, and medium firms operating in Tehran. The questionnaire was sent to the list. To increase the response rate, a follow-up telephone call was placed, and a second mailing of the questionnaire was used. The mail survey was sent to 600 firms randomly whose mail address was available. We received 317 responses, of which 72 were incomplete. Considering the research criteria, the remaining 245 valid and complete questionnaires were used for further analysis through the SPSS and AMOS software (Fig. 2).

The survey instrument of this study included scales designed to measure the entrepreneurial orientation, market orientation, entrepreneurial leadership, and firm growth. Furthermore, all items for the constructs utilized in the present 


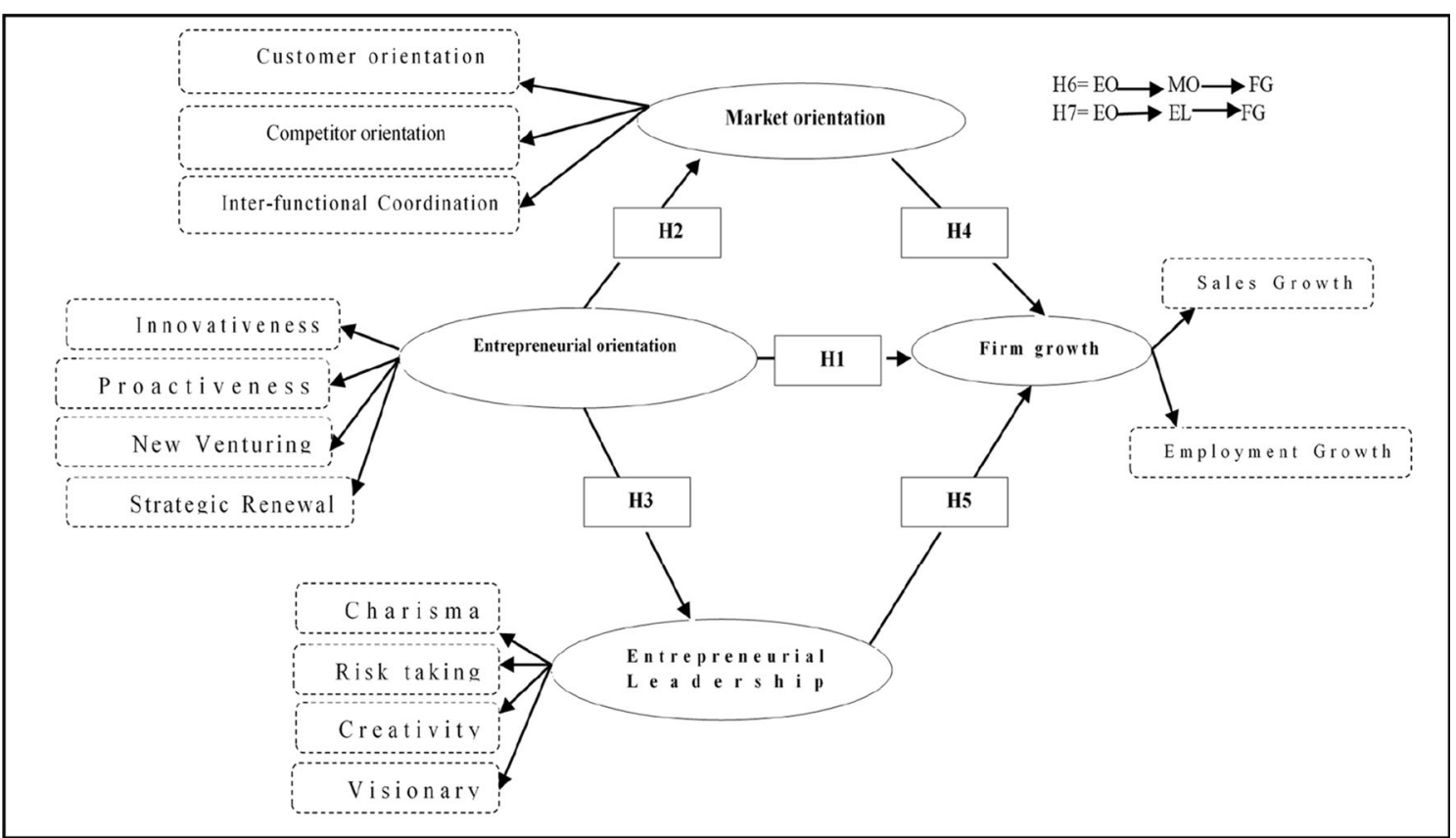

Fig. 1 Conceptual model of the research

study have been assessed on 5-point Likert scales, ranging from 1 (strongly disagree) to 5 (strongly agree).

Entrepreneurial orientation. Measurement of EO has been performed across four dimensions, i.e., innovativeness (4 items), proactiveness ( 3 items), new business venturing (5 items), and strategic renewal (4 items), by combining works of Lumpkin and Dess (1996), Chen et al. (2012), and Cools \& Van den Broeck, 2007).

Market orientation. This study has utilized the work of Slater and Narver (1994), and Nasution et al. (2011), to measure market orientation dimensions. Hence, the dimensions are customer orientation (5 items), competitor orientation (4 items), and inter-functional coordination (4 items).

Entrepreneurial leadership. The measures of entrepreneurial leadership have been developed by combining the works of Zijlstra (2014) and Renko et al. (2015) in this study. The scale of entrepreneurial leadership is composed of four components: visionary (5 items), charisma (4 items), creativity (3 items), risk-taking (3 items).

Firm growth. For measuring of firm growth, the works of Naldi and Davidsson (2014), Ferreira and Azevedo (2008), and Aaboen et al. (2006) were adopted. According to these works, the dimensions of firm growth
Fig. 2 Number of ASMEs analyzed by different cities of Tehran Province

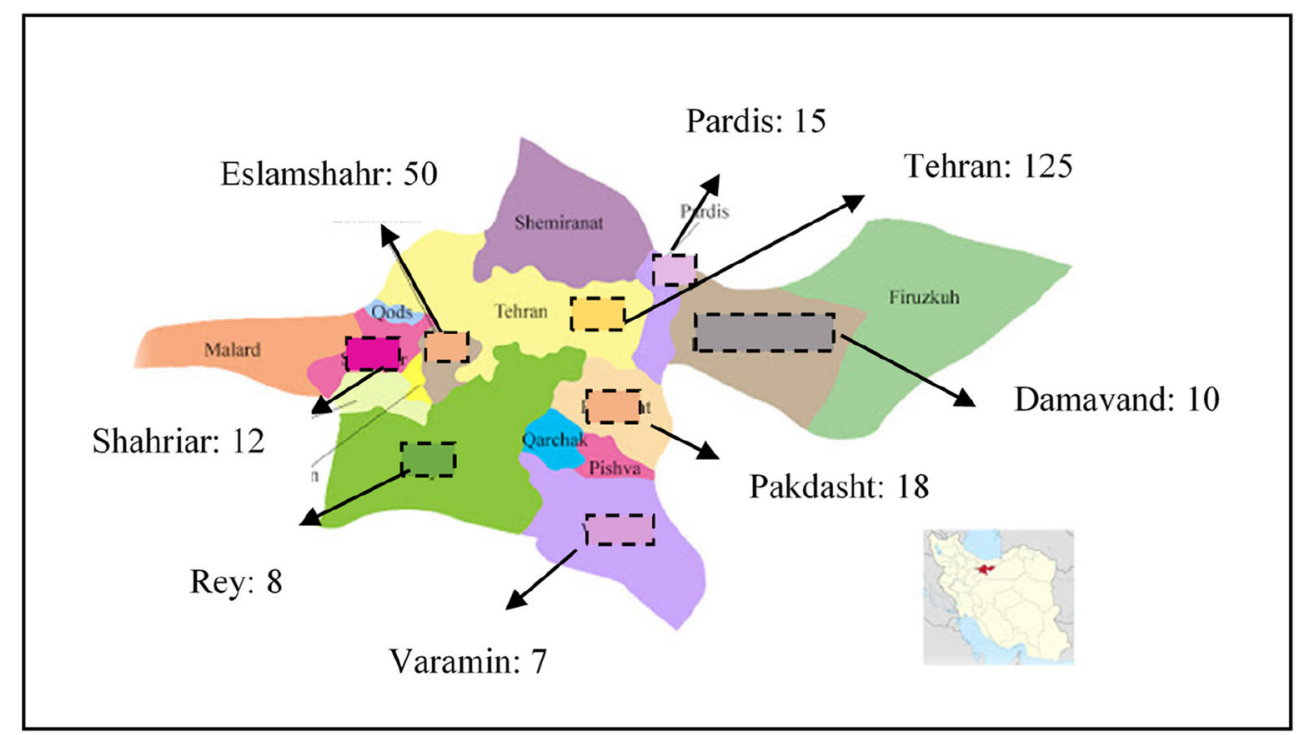


Table 1 Average variance extracted (AVE), composite reliability (CR), and square root of the average variance extracted and correlations of all constructs

\begin{tabular}{|c|c|c|c|c|c|c|}
\hline Construct & $\mathrm{CR}$ & AVE & $\mathrm{EO}$ & $\begin{array}{l}\text { Market } \\
\text { orientation }\end{array}$ & $\begin{array}{l}\text { Entrepreneurial } \\
\text { leadership }\end{array}$ & Growth \\
\hline EO & 0.85 & 0.72 & $0.848^{*}$ & & & \\
\hline Market orientation & 0.89 & 0.80 & 0.698 & $0.894 *$ & & \\
\hline $\begin{array}{l}\text { Entrepreneurial } \\
\text { leadership }\end{array}$ & 0.83 & 0.78 & 0.711 & 0.698 & $0.883^{*}$ & \\
\hline Growth & 0.80 & 0.75 & 0.783 & 0.739 & 0.741 & $0.866^{*}$ \\
\hline
\end{tabular}

*The gray area indicates the square root of the average variance extracted of the construct are sales growth (5 items) and employment growth (5 items).

In this study, the hypothesized relationships were investigated using AMOS20 graphic software, a structural equation modeling (SEM) method. It should be noted that the bootstrapping method was used for the sixth and seventh hypotheses, i.e., the mediation effect of market orientation and entrepreneurial leadership on the relationship between EO and firm's growth (Preacher and Hayes, 2008). In this method, firstly, the total effect model or the direct effect of the independent variable on the dependent variable is estimated without the presence of the mediator variable; if this effect is significant, the model in the second step is estimated and examined with the mediation effect that includes the mediator variable. In the event of a significant indirect path in this model, the mediation hypothesis is confirmed (Hayes, 2017).

Content validity. At the first stage, the content validity had been examined by eight managers with at least five years of experience in the agricultural SMEs and eight academics and experts before distributing the questionnaires. Then, the questionnaire was revised based on their comments.

Discriminant validity. In order to measure discriminant validity, it is essential that the square root of the average variance extracted (AVE) of each construct should be higher than the correlation shared between the construct and other constructs in the model and should be at least 0.50 (Fornell \& Larcker, 1981). Table 3 displays the correlation and the square of the AVE. As Table 3 indicates, all constructs satisfactorily pass the test, as the square root of the AVE (on the diagonal) is larger than the cross-correlations with other constructs. Hence, the discriminant validity of the model is accepted (Table 1).

Internal consistency reliability. Reliability has been measured first by using Cronbach's alpha coefficient through SPSS. Cronbach's alpha is calculated to examine the reliability, which was higher than 0.7 for the individual constructs of the questionnaire (Sekaran, 1984). Cronbach's alpha values for the individual constructs in this study were higher than 0.7 (Table 2).

Table 2 displays the descriptive statistics of variables, namely means (M), standard deviations (SD), and Spearman correlation coefficients. The results of Table 2 indicate that ASMEs in Tehran have used the factor of new venturing (SD: 2.82) more than the other dimensions of entrepreneurial orientation. Additionally, customer orientation (SD: 3.77 ) and vision (SD: 3.21 ) have the highest values. The correlation matrix shows that there is a significant and positive correlation ( $p<0.05$ or $0 / 01$ ) between firm growth and other variables.

Table 2 Descriptive statistics and correlation matrix

\begin{tabular}{|c|c|c|c|c|c|c|c|c|c|c|c|c|c|c|c|}
\hline Variable & M & $\mathrm{SD}$ & $\mathrm{C} \alpha$ & 1 & 2 & 3 & 4 & 5 & 6 & 7 & 8 & 9 & 10 & 11 & 12 \\
\hline Proactiveness & 2.782 & 1.34 & 0.79 & 1 & & & & & & & & & & & \\
\hline Innovativeness & 2.403 & 1.17 & 0.81 & $0.45 * *$ & 1 & & & & & & & & & & \\
\hline New business venturing & 2.820 & 1.34 & 0.83 & $0.63 * *$ & $0.38 * *$ & 1 & & & & & & & & & \\
\hline Strategic renewal & 2.682 & 1.61 & 0.74 & $0.54 * *$ & $0.46^{* *}$ & $0.41 * *$ & 1 & & & & & & & & \\
\hline Inter-functional coordination & 3.011 & 1.72 & 0.80 & $0.61 * *$ & $0.46^{* *}$ & $0.39 * *$ & $0.42 * *$ & 1 & & & & & & & \\
\hline Competitor orientation & 3.321 & 1.20 & 0.81 & $0.41 * *$ & $0.45^{* *}$ & $0.46^{* *}$ & 0.11 & $0.31 * *$ & 1 & & & & & & \\
\hline Customer orientation & 3.771 & 1.66 & 0.78 & $0.21 *$ & $0.33 * *$ & $0.22 *$ & $0.28 * *$ & $0.47 * *$ & $0.41 * *$ & 1 & & & & & \\
\hline Risk-taking & 2.412 & 1.31 & 0.77 & $0.42 * *$ & $0.45^{* *}$ & $0.37 * *$ & $0.50 * *$ & $0.51 * *$ & $0.58 * *$ & $0.38 * *$ & 1 & & & & \\
\hline Visionary & 3.210 & 1.03 & 0.72 & $0.31 * *$ & $0.37^{* *}$ & $0.42 * *$ & $0.44 * *$ & $0.39 * *$ & $0.46^{* *}$ & $0.42 * *$ & $0.34 *$ & 1 & & & \\
\hline Charisma & 2.467 & 1.41 & 0.75 & 0.02 & $0.39 * *$ & $0.52 * *$ & $0.54 * *$ & $0.37 * *$ & $0.40 * *$ & $0.39 * *$ & $0.39 * *$ & $0.41 * *$ & 1 & & \\
\hline Creativity & 3.162 & 1.14 & 0.78 & $0.28 * *$ & $0.51 * *$ & $0.44 * *$ & $0.52 * *$ & $0.39 * *$ & 0.07 & $0.44 * *$ & $0.41 * *$ & $0.37 * *$ & $0.45 * *$ & 1 & \\
\hline Firm growth & 2.719 & 1.01 & 0.82 & $0.42 * *$ & $0.37^{* *}$ & $0.42 * *$ & $0.47 * *$ & $0.48 * *$ & $0.31 * *$ & $0.39 * *$ & $0.33 * *$ & $0.29 * *$ & $0.37 * *$ & $0.40 * *$ & 1 \\
\hline
\end{tabular}


Table 3 Goodness-of-fit statistics

\begin{tabular}{lcccccc}
\hline Single fit indices & Relative chi-square & GFI & RMR & CFI & IFI & RMSEA \\
\hline Recommended guideline & $<3$ & $>0.90$ & $<0.05$ & $>0.90$ & $>0.90$ & $<0.10$ \\
Hair et al. (2006) & & & & & & \\
CE & 2.68 & 0.912 & 0.039 & 0.900 & 0.914 & 0.071 \\
KC & 2.46 & 0.908 & 0.043 & 0.907 & 0.927 & 0.080 \\
LO & 2.55 & 0.914 & 0.039 & 0.908 & 0.910 & 0.073 \\
P & 2.91 & 0.906 & 0.050 & 0.917 & 0.902 & 0.068 \\
\hline
\end{tabular}

Composite reliability. In the structural equation model, the measurement model is assessed by composite reliability (CR). Fornell and Larcker (1981) have suggested that CR values should be greater than 0.6. So, the values of composite reliability for the four subscales given in Table 3 are acceptable (Table 1).

Model goodness of fit (GOF). In assessing the model goodness of fit, Hair et al. (2013) suggested multiple criteria to be used, including CFA and structural model (Hair et al., 2013). The summary of the goodness-of-fit indices used in this study is presented in Table 3 .

\section{Analysis and results}

\section{Descriptive and correlation statistics}

Results show that among 245 ASMEs, 55\% have been established between 1995 and 2005 with a size between 9 and 49 employees that it is almost $79 \%$. The majority of them (48\%) have \$50,000-100,000 annual sales turnover (Table 4).

\section{Structural equation model}

Measurement model Following Anderson and Gerbing (1988), all constructs are allowed to correlate freely, but the indicators are set to correlate only with their constructs. A confirmatory factor analysis using AMOS20 is used to test the measurement model (i.e., to confirm the structure of constructs) (Hair et al., 2006). As shown in Tables 3 and 5, all indicator loadings for constructs were statistically significant $(\mathrm{p}<0.01)$, and their standardized estimates ranged from 0.668 to 0.875 for $\mathrm{EO}, 0.698$ to 0.860 for market orientation, 0.713 to 0.764 for entrepreneurial leadership, and 0.708 to 0.721 for firm growth. All of the indicators loaded significantly and substantively on their hypothesized factors $(\mathrm{p}<0.01)$, thereby suggesting convergent validity (Bagozzi \& Yi, 1988). Also, the measurement model shows the validity and reliability of the constructs described in the methodology. This suggests that the structural model represents a good fit. Thus, the path coefficients of the structural model can be examined.

\section{Structural model}

The results of path coefficients show that there is a significant relationship between EO and firm growth, then hypothesis 1 is confirmed. The result is in line with many researchers' studies that have concluded that the EO has a positive impact on firm performance (Kraus et al., 2012; Fairoz et al., 2010; Hosseini \& Eskandari, 2013). The results of the second hypothesis, which has emphasized the relationship between EO and market orientation, are presented in Fig. 3 and Table 6. The path coefficients and t-value for this hypothesis were extracted respectively 0.496 and 3.684 , meaning this hypothesis was also accepted. This finding is supported by previous literature about direct relationships between EO and MO (Maleki et al., 2013; Ghanavati, 2014).

Table 4 Profile of the respondents

\begin{tabular}{llllc}
\hline & F & Percent & F & Percent \\
\hline $\begin{array}{l}\text { Enterprise year of establishment } \\
\text { Before 1995 }\end{array}$ & 69 & 28.2 & $\begin{array}{l}\text { Enterprise size of employment } \\
\text { Less than 9 employees }\end{array}$ & 11 \\
1995-2005 After 2005 & 13541 & 55.116 .7 & $\begin{array}{l}\text { Between 9 and 49 employeesAbove } \\
50 \text { employees }\end{array}$ & 19341 \\
Nature of business & & & Enterprise annual sales turnover & 78.816 .7 \\
Production & 117 & 47.7 & Below $\$ 50,000$ & 36 \\
Service & 89 & 36.4 & \$50,000-100,000 & 14.7 \\
Others & 39 & 15.9 & Above $\$ 100,000$ & 57.6 \\
\hline
\end{tabular}


Table 5 Measurement model results

\begin{tabular}{|c|c|c|c|c|c|c|}
\hline Construct & Indicator & Standardized loadings & Critical ratio & $\mathrm{CR}$ & AVE & $\mathrm{C} \alpha$ \\
\hline \multirow[t]{4}{*}{$\mathrm{EO}$} & Proactiveness & 0.845 & 3.79 & \multirow[t]{4}{*}{0.810} & \multirow[t]{4}{*}{0.541} & \multirow[t]{4}{*}{0.814} \\
\hline & New business $\mathrm{V}$ & 0.768 & 3.87 & & & \\
\hline & Innovativeness & 0.875 & 3.23 & & & \\
\hline & Strategic renewal & 0.668 & 2.98 & & & \\
\hline \multirow[t]{3}{*}{ Market orientation } & Inter-functional & 0.698 & 2.74 & \multirow[t]{3}{*}{0.795} & \multirow[t]{3}{*}{0.511} & \multirow[t]{3}{*}{0.743} \\
\hline & Competitor orientation & 0.860 & 3.30 & & & \\
\hline & Customer orientation & 0.774 & 2.12 & & & \\
\hline \multirow[t]{4}{*}{ Entrepreneurial leadership } & Charisma & 0.720 & & \multirow[t]{4}{*}{0.771} & \multirow[t]{4}{*}{0.563} & \multirow[t]{4}{*}{0.810} \\
\hline & Risk-taking & 0.713 & 2.74 & & & \\
\hline & Visionary & 0.764 & 3.20 & & & \\
\hline & Creativity & 0.749 & 3.75 & & & \\
\hline \multirow[t]{2}{*}{ Firm growth } & Sales growth & 0.721 & 3.32 & \multirow[t]{2}{*}{0.804} & \multirow[t]{2}{*}{0.541} & \multirow[t]{2}{*}{0.846} \\
\hline & Employment growth & 0.708 & 3.73 & & & \\
\hline
\end{tabular}

In the relationship between EO and entrepreneurial leadership (hypothesis 3), the result shows that corporate EO has a positive correlation with entrepreneurial leadership $(\mathrm{P}=0.513$, $\mathrm{t}=2.693, \mathrm{p}<0.001)$. Thus, hypothesis 3 is supported. Furthermore, these findings have good fitness with previous studies (Agbim et al., 2013; El-Annan, 2013; Renko et al., 2015). The fourth hypothesis supports the positive effect of market orientation on firm growth. This hypothesis, according to the path coefficient of 0.375 , and the amount of 3.473 for $t-$ value, is supported. The results confirm previous studies that have shown the direct relationships between $\mathrm{MO}$ and firm growth (Micheels \& Gow, 2008; Rahab, 2012). As shown in Fig. 4 and Table 6 , the findings confirm a positive effect between entrepreneurial leadership and firm growth $(\mathrm{P}=0.471$, $\mathrm{t}=2.681$ ), which supports the fifth hypothesis. Also, the findings are consistent with previous works such as Lockett et al., 2013), Jagdale \& Bhola (2014), and Koryak et al. (2015).

This research examines whether market orientation and entrepreneurial leadership mediate the relationship between EO and firm growth. The obtained results from the implementation of the bootstrapping method indicate that the sum of the indirect effect of entrepreneurial orientation on firm growth through the variable of market orientation is significant $(\rho=0.000, \beta=0.391)$. Thus, the sixth hypothesis is confirmed (Table 7), since the direct path between EO and firm growth in the mediation effect model is positive and significant ( $\rho$-value $=0.003, \beta=0.440$ ). Thus, market orientation partially mediates the positive effect of EO and firm growth (Pahlavan Sharif and Mahdavian, 2015). Previous empirical findings also support the findings of the mediating role of market orientation in the relationship between EO and firm growth. Concerning H7, EO significantly affects firm growth via entrepreneurial leadership. The results obtained from the implementation of the bootstrapping method indicates that the sum of the indirect effect of EO on firm growth through the variable of entrepreneurial leadership is significant ( $\rho$-value $=0.001, \beta=$ 0.368). Thus, the seventh hypothesis is confirmed (see Table 7).

Since the direct path between EO and firm growth in the mediation effect model is positive and significant $(\rho$-value $=0.001$, $\beta=0.486$ ), the learning orientation partially mediates the positive effect of EO on firm growth. Previous empirical findings also supported the findings regarding the mediating role of learning orientation in the relationship between EO and firm growth. For instance, Calantone et al. (2002) and Baker and Sinkula (2002) have shown the mediating role of learning orientation in the

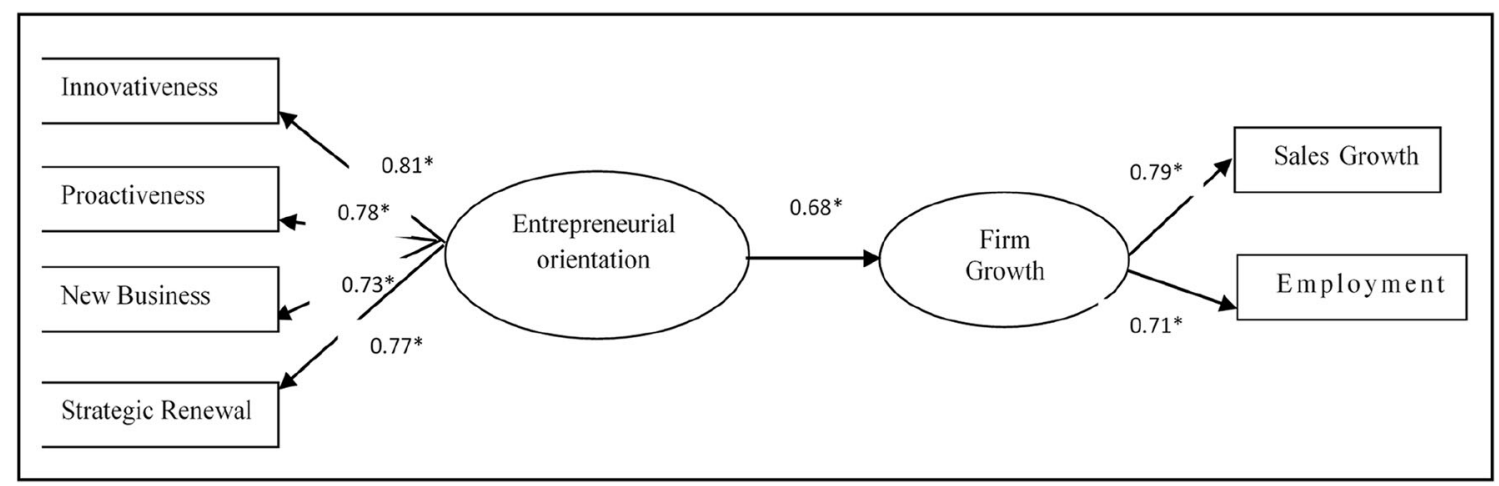

Fig. 3 Direct structural model EO and firm growth with standardized estimates 
Table 6 The direct hypothesis tests summary

\begin{tabular}{lllllrrr}
\hline Hypothesis & Content & Unstandardized estimates & S.E. & Standardized estimates & Critical ratio & Sig. & Support \\
\hline $\mathrm{H} 1$ & $\mathrm{EO} \rightarrow \mathrm{FG}$ & 0.768 & 0.128 & 0.676 & 6.00 & 0.001 & Yes \\
$\mathrm{H} 2$ & $\mathrm{EO} \rightarrow \mathrm{MO}$ & 0.821 & 0.117 & 0.647 & 7.01 & .0 .000 & Yes \\
$\mathrm{H} 3$ & $\mathrm{EO} \rightarrow \mathrm{EL}$ & 0.783 & 0.075 & 0.626 & 10.44 & 0.000 & Yes \\
$\mathrm{H} 4$ & $\mathrm{MO} \rightarrow \mathrm{FG}$ & 0.827 & 0.151 & 0.607 & 5.47 & 0.001 & Yes \\
$\mathrm{H} 5$ & $\mathrm{EL} \rightarrow \mathrm{FG}$ & 0.779 & 0.093 & 0.545 & 8.37 & 0.000 & Yes \\
\hline
\end{tabular}

relationship between EO and firm growth. As presented in Tables 6 and 7, all path coefficients are significant at the 0.01 level in the structural model. The results indicate that the hypothesized relationships are supported. The explanatory power of the structural model is evaluated by examining the amount of variance in the dependent variable, which can be explained by the model. Squared multiple correlations $\left(\mathrm{R}^{2}\right)$ were computed for the dependent variable (firm growth) in a model. The criterion, $\mathrm{R}^{2}$, is critical in evaluating a structural model. Based on the results, EO explains about $46 \%$ of the variances of firm growth (Fig. 3).

Besides, as Fig. 4 indicates, two variables of EO and market orientation explain about $53 \%$ of the variances of firm performance, which shows a $7 \%$ increase compared to the direct structural model.

Also, in Fig. 5, two variables of EO and entrepreneurial leadership explain about $57 \%$ of the variances of firm performance, which shows an $11 \%$ increase compared to the direct structural model.

\section{Discussion}

The speed of environmental changes, the development of technology, and knowledge in the market, along with the development of political economy among nations, have led to the important role of agriculture among countries. Hence, ASMEs play an important role in developing countries, including Iran, to progress and develop organizations. Dealing with changes, identifying opportunities quickly, and turning them into strengths for organizations to grow and flourish require different thinking processes in the management of an organization called organizational entrepreneurship. In the review of the related literature, the EO has been discussed as an important issue. Lumpkin and Dess (1996) regarded the EO as one of the four main dimensions of organizational entrepreneurship. Vidic (2013) defines $\mathrm{EO}$ as a process to facilitate the application of the knowledge needed in order to discover and take advantage of environmental opportunities.

Some studies like Fairoz et al. (2010) and Avlonitis and Salavou (2007) have researched on the impact of EO on performance; however, these studies show a partial picture of the impact of EO on performance since they have considered a direct effect regardless of the mediating variables.

To address this paucity, several variables as a mediator in facilitating the relationship between EO and performance have been used in other studies. For example, Avlonitis and Salavou (2007) employed product innovation as a mediator in

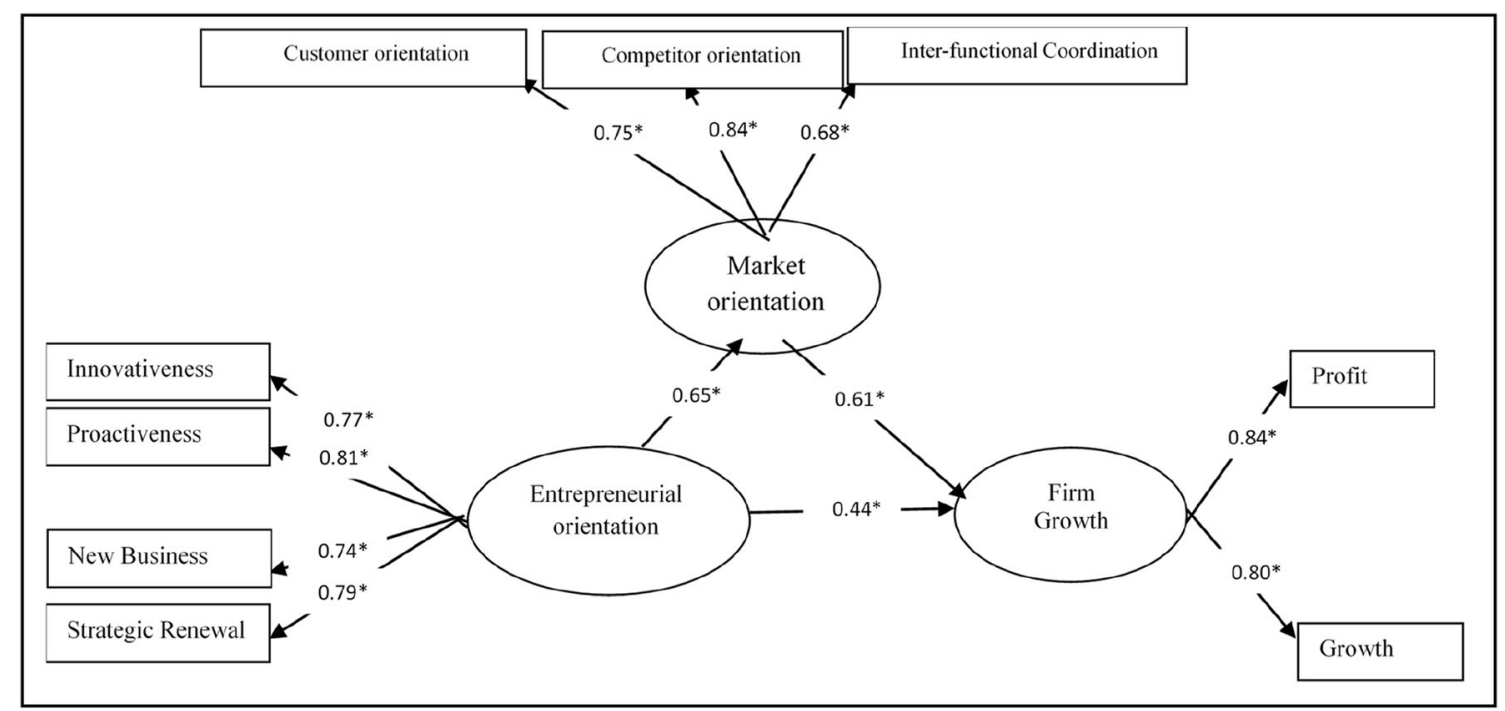

Fig. 4 Mediation structural model with standardized estimates for MO 
Table 7 The mediation hypothesis tests summary

\begin{tabular}{llllllll}
\hline Hypothesis & Content & $\begin{array}{l}\text { Indirect } \\
\text { standardized } \\
\text { estimates }\end{array}$ & & Indirect effect S.E. & Confidence intervals & Two-tailed sig. (PC) & Support \\
\cline { 3 - 6 } & & & Lower bounds (PC) & Upper bounds (PC) & \\
\hline $\mathrm{H} 4$ & $\mathrm{EO} \rightarrow \mathrm{MO} \rightarrow \mathrm{FG}$ & 0.391 & 0.061 & 0.566 & 4.631 & 0.000 & Yes \\
$\mathrm{H} 5$ & $\mathrm{EO} \rightarrow \mathrm{EL} \rightarrow \mathrm{FG}$ & 0.368 & 0.043 & 0.508 & 4.730 & 0.001 & Yes \\
\hline
\end{tabular}

the relationship between EO and performance in SMEs. Vidic (2013) investigated 195 SMEs and inspected the relationship between EO and the creation of knowledge and their impact on performance. In another study, Hassim et al. (2011) examined the effect of EO on organizational performance via the intermediary role of market orientation. Moreover, Hunter (2013) used the mediating role of entrepreneurial leadership to examine the competitiveness of SMEs producing food and drink in the southwest UK. EO recognizes opportunities through capabilities like market orientation and entrepreneurial leadership. Because of the uncertainties in the environment, organizations need marketing intelligence to survive and grow and to quickly predict customers' changing needs as well as competitors' strengths and weaknesses. Market orientation helps organizations to achieve this goal by increasing the capacity to absorb information about the environment and the types of customers and competitors.

Leadership, in many SMEs, is a collective activity that a team takes decisions on how to identify and exploit opportunities. As a result, in such an organization, several capabilities are required to coordinate the various teams and departments. Entrepreneurial leadership and market orientation are considered essential capabilities for it. The conceptual model of this study has incorporated market orientation and entrepreneurial leadership as mediating variables, and the results indicate that EO using such capabilities is essential for the ASMEs.

\section{Conclusion}

This study is a conceptual study to examine the intermediary role of the two variables of market orientation and entrepreneurial leadership in the relationship between EO and growth of ASMEs in Tehran Province in Iran. Analyses were conducted utilizing structural equation modeling in the AMOS software and standardized path coefficient calculation. While all of the research hypotheses were confirmed, the results were consistent with previous studies. The standardized path coefficients reflect the strong relationship between the independent, dependent, and mediating variables in the model.

\section{Implications}

This study carries a series of implications for executives, entrepreneurs, employees, and academics. It implies that the roles of all the individuals in an organization are of importance in all dimensions. This study could promote a culture of risktaking and innovation among researchers and all the employees of the companies. The results show that organizations with an EO can quickly identify customers, competitors, and the business environment through the growth and development of its research and development department, together with attention to market orientation.

EO can also lead to strategic modernization, innovation, proactiveness, and the creation of a new business in an

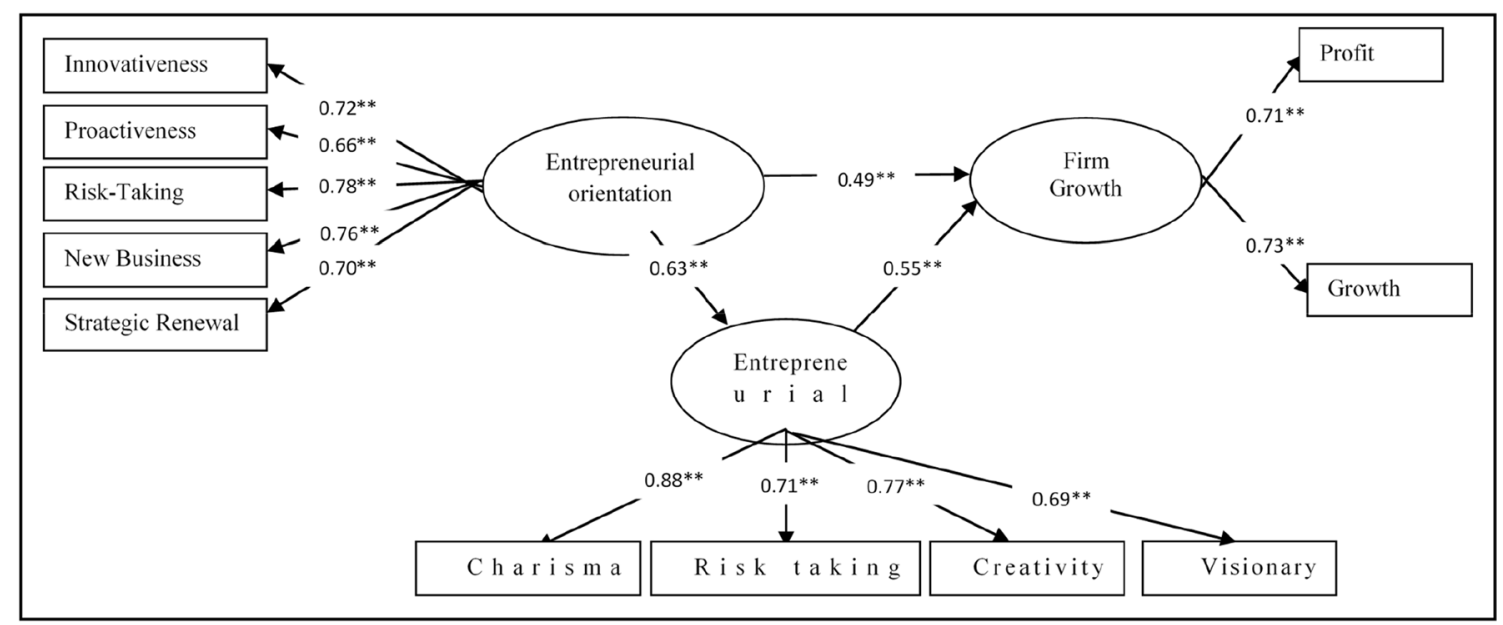

Fig. 5 Mediation structural model with standardized estimates for EO 
existing organization. Also, entrepreneurial leadership helps managers and leaders to create a leading spirit in all individuals and brings about a collective leadership in an organization. Individuals of an organization can participate in decisionmaking to increase the income of the organization and achieve the organizations' growth via new research methods in various areas, and through rapid commercialization of their innovative products.

\section{Limitations}

In the present study, the researchers were faced with some limitations. One of the most important limitations was the lack of detailed financial data for SMEs, which was of importance in the assessment and financial analysis to evaluate growth rates. Another limitation of the study was the failure to respond to the questionnaire submitted or the presence of inappropriate responses so that from the 600 questionnaires sent, only 317 questionnaires were answered, and only 245 questionnaires were of use. This process resulted in a waste of time and increased cost of the study for the researchers.

\section{Future studies}

As for recommendations for future studies, qualitative studies may develop a deeper understanding of the relationship between EO and the organization's growth through the mediating role of market orientation and entrepreneurial leadership. Given the importance of ASMEs in Iran, there are not many studies to examine the supply chain in this industry. It is recommended to study the agricultural sector, especially SMEs, in future research. Also, it is suggested to devise a more comprehensive framework with different environmental factors. The results of this study are only about ASMEs in Tehran Province. Therefore, it is recommended to examine this model in other sectors of industry and services as well as large organizations.

\begin{abstract}
Abbreviations ASMEs, agricultural small- and medium-sized enterprises; $G D P$, gross domestic product; $G N I$, gross national income; $E O$, entrepreneurial orientation; $C R$, composite reliability; $G O F$, goodness of fit
\end{abstract}

Acknowledgements This study would like to express sincere gratitude to owners and top managers of ASMEs in Iran for their encouragement and assistance during the data collection.

Author contribution Professor Mahmood Ahmadpour Daryani has worked in conceptualization of the research, design of research methodology, and overall supervision of the study. Dr. Asef Karimi has worked in the data analysis and data collection. Mrs. Soma Rahmani has done literature review part and data collection. All of the authors have read the final draft and approved for submission.
Data availability This dataset was generated by sending questionnaires and mail surveys to owners and/or top managers of agricultural small- and medium-sized enterprises in Tehran, Iran. Then, the datasets used in this study are available from the corresponding author on reasonable request.

\section{Declarations}

Competing interests The authors declare no competing interests.

Open Access This article is licensed under a Creative Commons Attribution 4.0 International License, which permits use, sharing, adaptation, distribution and reproduction in any medium or format, as long as you give appropriate credit to the original author(s) and the source, provide a link to the Creative Commons licence, and indicate if changes were made. The images or other third party material in this article are included in the article's Creative Commons licence, unless indicated otherwise in a credit line to the material. If material is not included in the article's Creative Commons licence and your intended use is not permitted by statutory regulation or exceeds the permitted use, you will need to obtain permission directly from the copyright holder. To view a copy of this licence, visit http://creativecommons.org/licenses/by/4.0/.

\section{References}

Aaboen, L., Lindelöf, P., Von Koch, C., \& Löfsten, H. (2006). Corporate governance and performance of small high-tech firms in Sweden. Technovation, 26(8), 955-968.

Agbim, K. C., Oriarewo, G. O., \& Owutuamor, Z. B. (2013). An exploratory study of the entrepreneurial leadership capabilities of entrepreneurs in Anambra State. Nigeria. Journal of Business Management \& Social Sciences Research, 2(9), 68-75.

Aljanabi, A. R. A., Noor, M., \& Azila, N. (2015). The mediating role of market orientation on entrepreneurial orientation, absorptive capacity and technological innovation capabilities. Asian Social Science, 11(5), 219-234.

Anderson, J. C., \& Gerbing, D. W. (1988). Structural equation modeling in practice: A review and recommended two-step approach. Psychological Bulletin, 103(3), 411.

Antoncic, B., \& Hisrich, R. D. (2001). Intrapreneurship: Construct refinement and cross-cultural validation. Journal of Business Venturing, $16(5), 495-527$.

Arasti, Z., Zandi, F., \& Bahmani, N. (2014). Business failure factors in Iranian SMEs: Do successful and unsuccessful entrepreneurs have different viewpoints? Journal of Global Entrepreneurship Research, 4(1), 10.

Avlonitis, G. J., \& Salavou, H. E. (2007). Entrepreneurial orientation of SMEs, product innovativeness, and performance. Journal of Business Research, 60(5), 566-575.

Awwad, M. S., \& Agti, D. A. M. (2011). The impact of internal marketing on commercial banks' market orientation. The International Journal of Bank Marketing, 29(4), 308-332.

Bagozzi, R. P., \& Yi, Y. (1988). On the evaluation of structural equation models. Journal of the Academy of Marketing Science, 16(1), 74 94.

Baker, W. E., \& Sinkula, J. M. (2002). Market orientation, learning orientation and product innovation: Delving into the organization's black box. Journal of Market-Focused Management, 5(1), 5-23.

Bartlett, J. E., Kotrlik, J. W., \& Higgins, C. C. (2001). Organizational research: Determining appropriation sample size in survey research. Information technology. Learning and performance journal., 19(1), $43-50$. 
Boso, N., Story, V. M., \& Cadogan, J. W. (2013). Entrepreneurial orientation, market orientation, network ties, and performance: Study of entrepreneurial firms in a developing economy. Journal of Business Venturing, 28(6), 708-727.

Calantone, R. J., Cavusgil, S. T., \& Zhao, Y. (2002). Learning orientation, firm innovation capability, and firm performance. Industrial Marketing Management, 31(6), 515-524.

Chen, Y. C., Li, P. C., \& Evans, K. R. (2012). Effects of interaction and entrepreneurial orientation on organizational performance: Insights into market driven and market driving. Industrial Marketing Management, 41(6), 1019-1034.

Cools, E., \& Van den Broeck, V. (2007). The hunt for the heffalump continues: Can trait and cognitive characteristics predict entrepreneurial orientation? Journal of Small Business Strategy, 18(2), 2342.

Coulthard, M. (2007). The role of entrepreneurial orientation on firm performance and the potential influence of relational dynamism. Journal of Global Business and Technology, 3(1), 29-39.

EL-Annan, S. H. (2013). Innovation, proactive, and vision are three integrated dimensions between leadership and entrepreneurship. European Journal of Business and Social Sciences, 1(12), 148-163.

Fairoz, F. M., Hirobumi, T., \& Tanaka, Y. (2010). Entrepreneurial orientation and business performance of small and medium scale enterprises of Hambantota District Sri Lanka. Asian Social Science, 6(3), 34.

Ferreira, J., \& Azevedo, S. G. (2008). Entrepreneurial orientation (EO) and growth of firms: Key lessons for managers and business professionals. Problems and Perspectives in Management, 6(1), 82-88.

Fornell, C., \& Larcker, D. F. (1981). Evaluating structural equation models with unobservable variables and measurement error. Journal of Marketing Research, 18(1), 39-50.

Gellynck, X., Cárdenas, J., Pieniak, Z., \& Verbeke, W. (2015). Association between innovative entrepreneurial orientation, absorptive capacity, and farm business performance. Agribusiness, 31(1), 91-106.

Ghanavati, M. (2014). The effect of corporate culture and market orientation on Iranian industrial SMEs' performance. Iranian Journal of Management Studies, 7(2), 413-436.

Gürbüz, G., \& Aykol, S. (2009). Entrepreneurial management, entrepreneurial orientation and Turkish small firm growth. Management Research News, 32(4), 321-336.

Hair, J. F., Black, W. C., Babin, B. J., Anderson, R. E., \& Tatham, R. L. (2006). Multivariate data analysis (6 ed.): Prentice Hall.

Hair, J. F., Ringle, C. M., \& Sarstedt, M. (2013). Partial least squares structural equation modeling: Rigorous applications, better results and higher acceptance. Long Range Planning, 46(1-2), 1-12.

Hassim, A. A., Asmat-Nizam, A. T., \& Bakar, A. R. A. (2011). The effects of entrepreneurial orientation on firm organizational innovation and market orientation towards firm business performance. International on Sociality ND Economics Development. IPEDR, $10,280-284$

Hayes, A. F. (2017). Introduction to mediation, moderation, and conditional process analysis: A regression-based approach. Guilford publications.

Hosseini, M., \& Eskandari, F. (2013). Investigating entrepreneurial orientation and firm performance in the Iranian agricultural context. Journal of Agricultural Science and Technology, 15, 203-214.

Huang, S., Ding, D., \& Chen, Z. (2014). Entrepreneurial leadership and performance in Chinese new ventures: A moderated mediation model of exploratory innovation, exploitative innovation and environmental dynamism. Creativity and Innovation Management, 23(4), 453-471.

Hunter, Lise (2013). The mediating role of entrepreneurial leadership: An investigation of the competitiveness of SMEs in the UK south West Food and Drink Manufacturing. Ph.D. Disseertation, University of Plymouth.
Hussain, J., Kamariah, I., Shoaib, C., \& Akhtar. (2015). Market orientation and organizational performance: A case of Pakistani SMEs. Social and Basic Sciences Research Review, 3(2), 125-136.

Hussain, J., Shah, F. A., \& Akhtar, C. S. (2016). Market orientation and organizational performance in small and medium sized enterprises. A conceptual approach. City University Research Journal, 6(1), 166-180.

Hyypiä, M., \& Parjanen, S. (2013). Boosting creativity with transformational leadership in fuzzy front-end innovation processes. Interdisciplinary Journal of Information, Knowledge, and Management, 8, 21-41.

Jagdale, D., \& Bhola, S. S. (2014). Entrepreneurial leadership and organizational performance with reference to rural small scale engineering industry in Pune district. Golden Research Thoughts, 4(2), 1-9.

Kabiri, F., \& Mokshapathy, S. (2013). Entrepreneurial orientation and export performance in SMEs (case study of fruits and vegetables SMEs in Iran). International Journal of Agronomy and Plant Production, 4(S), 3709-3718.

Kajalo, S., \& Lindblom, A. (2015). Market orientation, entrepreneurial orientation and business performance among small retailers. International Journal of Retail \& Distribution Management, 43(7).

Khorami, A. R., \& Pierof, S. (2013). The role of agriculture in Iran's economic development. Research Journal of Applied Sciences, Engineering and Technology, 6(11), 1928-1939.

Koryak, O., Mole, K. F., Lockett, A., Hayton, J. C., Ucbasaran, D., \& Hodgkinson, G. P. (2015). Entrepreneurial leadership, capabilities and firm growth. International Small Business Journal, 33(1), 89105.

Kraus, S., Rigtering, J. C., Hughes, M., \& Hosman, V. (2012). Entrepreneurial orientation and the business performance of SMEs: A quantitative study from the Netherlands. Review of Managerial Science, 6(2), 161-182.

Lee, J. (2008). Effects of leadership and leader-member exchange on innovativeness. Journal of Managerial Psychology, 23(6), 670 687.

Liu, H., Ke, W., Wei, K. K., \& Hua, Z. (2013). Effects of supply chain integration and market orientation on firm performance. International Journal of Operations \& Production Management, 33(3), 322-346.

Lockett, A., Hayton, J., Ucbasaran, D., Mole, K., \& Hodgkinson, G. P. (2013). Entrepreneurial leadership, capabilities and growth. Enterprise Research Center, 2, 1-66.

Lumpkin, G. T., \& Dess, G. G. (1996). Clarifying the entrepreneurial orientation construct and linking it to performance. Academy of Management Review, 21(1), 135-172.

Maleki, A., Ansari, A., \& Safari, A. (2013). A study of market orientation and its effect on small to medium sized enterprises of informatics industry located in Tehran. Journal of Novel Applied Sciences, 2(4), $1150-1159$.

Maydeu-Olivares, A., \& Lado, N. (2003). Market orientation and business economic performance. International Journal of Service Industry Management, 14(3).

Micheels, E. T., \& Gow, H. R. (2008). Market orientation and profitability: Evidence from homogeneous markets. Paper presented at the American Agricultural Economics Association Annual Meeting.

MousaviHejazi, A., Mehdi, M., Maleki, M. J., \& Naeiji. (2012). Designing a scale for measuring entrepreneurial leadership in SMEs. Paper presented at the International Conference on Economics Marketing and Management.

Murray, J. Y., Gao, G. Y., \& Kotabe, M. (2011). Market orientation and performance of export ventures: The process through marketing capabilities and competitive advantages. Journal of the Academy of Marketing Science, 39(2), 252-269.

Naldi, L., \& Davidsson, P. (2014). Entrepreneurial growth: The role of international knowledge acquisition as moderated by firm age. Journal of Business Venturing, 29(5), 687-703. 
Nasution, H. N., Mavondo, F. T., Matanda, M. J., \& Ndubisi, N. O. (2011). Entrepreneurship: Its relationship with market orientation and learning orientation and as antecedents to innovation and customer value. Industrial Marketing Management, 40(3), 336-345.

Neely, A., \& Hii, J. (1998). Innovation and business performance: A literature review. The Judge Institute of Management Studies, 0-65.

Omar, R., Lim, K. Y., \& Basiruddin, R. (2014). Board of directors and small medium enterprise's firm growth with firm culture as moderating factor in Malaysia. Journal of Procedia - Social and Behavioral Sciences, 164, 315-323.

Pahlavan Sharif, S., \& Mahdavian, V. (2015). Structural equation modeling with Amos. Tehran: Publisher Bisheh.

Pearce, J. A., Fritz, D. A., \& Davis, P. S. (2010). Entrepreneurial orientation and the performance of religious congregations as predicted by rational choice theory. Entrepreneurship Theory and Practice, 34(1), 219-248.

Penrose, E. T. (1959). The theory of the growth of the firm. Oxford: Basil Blackwell.

Polonsky, M. J., Voss, Z. G., Voss, G. B., \& Moorman, C. (2005). An empirical examination of the complex relationships between entrepreneurial orientation and stakeholder support. European Journal of Marketing, 39(9/10), 1132-1150.

Popovic, B. S., Paunovic, T. Z., \& Maletic, Z. M. (2009). Development of SMES in agribusiness of Vojvodina communes-state and perspectives (No. 697-2016-47726, pp. 593-601).

Pourjavid, S., Sadighi, H., \& Shabanali, F. H. (2013). Analysis of constrains facing urban agriculture development in Tehran, Iran.

Preacher, K. J., \& Hayes, A. F. (2008). Asymptotic and resampling strategies for assessing and comparing indirect effects in multiple mediator models. Behavior Research Methods, 40, 879-891.

Prifti, R., \& Alimehmeti, G. (2017). Market orientation, innovation, and firm performance-An analysis of Albanian firms. Journal of Innovation and Entrepreneurship, 6(1), 8.

Rahab, S. (2012). Innovativeness model of small and medium enterprises based on market orientation and learning orientation: Testing moderating effect of business operation mode. Journal of Procedia Economics and Finance, 4, 97-109.

Rajes, Martin (2013). A behavioral theory of strategic renewal: The impact of performance feedback and organizational learning on strategic renewal actions. (Unpublished Ph.D. Dissertation, University of St. Gallen).

Renko, M., El Tarabishy, A., Carsrud, A. L., \& Brännback, M. (2015). Understanding and measuring entrepreneurial leadership style. Journal of Small Business Management, 53(1), 54-74.

Ruvio, A., Rosenblatt, Z., \& Hertz-Lazarowitz, R. (2010). Entrepreneurial leadership vision in nonprofit vs. for-profit organizations. The Leadership Quarterly, 21(1), 144-158.

Sekaran, U. (1984). Research methods for managers: A skill-building approach. John Wiley \& Sons.

Setyanti, S. W. L. H., Troena, E. A., Nimran, U., \& Rahayu, M. (2013). Innovation role in mediating the effect of entrepreneurship orientation, management capabilities and knowledge sharing toward business performance: Study at Batik SMEs in East Java Indonesia. IOSR Journal of Business and Management, 8(4), 16-27.

Sidik, G. I. (2012). Conceptual framework of factors affecting SME development: Mediating factors on the relationship of entrepreneur traits and SME performance. Journal of Procedia Economics and Finance, 4, 373-383.

Slater, S. F., \& Narver, J. C. (1994). Market orientation, customer value, and superior performance. Business Horizons, 37(2), 22-28.

Stenholm, P., Pukkinen, T., \& Heinonen, J. (2016). Firm growth in family businesses - The role of entrepreneurial orientation and the entrepreneurial activity. Journal of Small Business Management, 54(2), $697-713$.

Vidic, F. (2013). Entrepreneurial orientation (EO) and knowledge creation (KC). International Journal of Economic Sciences and Applied Research, 6(2), 103-124.

Zijlstra, H. P. (2014). Entrepreneurial leadership. (Unpublished Master Thesis, University of Twente). 